\title{
Assessment of Factors Constraining Organic Farming Expansion in Lis Valley, Portugal
}

\author{
Susana Ferreira ${ }^{1}$, Fátima Oliveira ${ }^{1,2}{ }^{\mathbb{D}}$, Francisco Gomes da Silva ${ }^{3}$, Margarida Teixeira ${ }^{4}$, \\ Madalena Gonçalves ${ }^{4}$, Rui Eugénio ${ }^{5}$, Henrique Damásio ${ }^{5}$ and José M. Gonçalves ${ }^{1, *(D)}$ \\ 1 Instituto Politécnico de Coimbra, Escola Superior Agrária de Coimbra, Coimbra, 3045-601 Coimbra, \\ Portugal; susana.ferreira@esac.pt (S.F.); foliveira@esac.pt (F.O.) \\ 2 IIA-Institute of Applied Research, CERNAS-Research Centre for Natural Resources, Environment and \\ Society, Coimbra, 3045-093 Coimbra, Portugal \\ 3 Instituto Superior de Agronomia, Universidade de Lisboa, Tapada da Ajuda, 1349-017 Lisboa, Portugal; \\ fgsilva@isa.ulisboa.pt \\ 4 Direção Regional de Agricultura e Pescas do Centro, Av. Fernão de Magalhães, Coimbra, 3000-177 Coimbra, \\ Portugal; margarida.teixeira@drapc.gov.pt (M.T.); madalena.goncalves@drapc.gov.pt (M.G.) \\ 5 Associação de Regantes e Beneficiários do Vale do Lis, Quinta do Picoto, Leiria, 2425-492 Souto da \\ Carpalhosa, Portugal; eugenio-rui@sapo.pt (R.E.); hdamasio71@gmail.com (H.D.) \\ * Correspondence: jmmg@esac.pt
}

Received: 30 December 2019; Accepted: 5 February 2020; Published: 10 February 2020

\begin{abstract}
Organic farming can play an important role in rural development and food production, by reinforcing the trend toward sustainable agriculture and its purpose of ecosystem conservation. The agribusiness of organic farming is particularly relevant in family farming, given the labor availability and the short marketing circuits. The innovative techniques of organic farming, namely with soil fertility, weed and pest control, opens a wide range of possibilities in its development and extension. The expectation of organic farming profitability in small-scale family farming, supported by known successful examples, were the theme of a field study on Lis Valley Irrigation District to assess the constraints to its expansion in order to outline the procedures for the acquisition of technical knowledge, the adaptation of technologies, the support for the conversion of production models, and the specialized training of farmers for action. Results revealed that the: (i) farmer's land structure, (ii) their mature age, (iii) low education level, and (iv) markets, are the main constrains for organic farming development. Furthermore, other uncertainties were identified, namely: (i) the certification process, (ii) the knowledge of new technologies, especially of crop protection, and (iii) the marketing problems to guaranteeing profitability. This study concludes that organic farming has significant potential for development in the Lis Valley and that the efforts and resources of the various stakeholders, namely the state, need to be harmonized to deliver effective support to farmers to promote organic farming that prioritizes: (i) rural development policies, (ii) supporting land restructuring, (iii) modernization of irrigation, (iv) stimulation of young farmers, (v) conversion and implementation of innovative technologies, (vi) the organization of farmers for better productive efficiency, and (vii) to facilitate market access.
\end{abstract}

Keywords: irrigation; Operational Groups; organic agriculture; rural development; rural reparcelling; land tenure

\section{Introduction}

Organic farming (OF) is an agricultural production system that sustains the demands of production of healthy and safe food, with no significant dependence on chemical fertilizers, using organic matter and bio-fertilizers, cultivating with reduced tillage, environmentally safe pest management and the 
adoption of integrated farming systems [1]. OF has the potential to contribute to rural development and food production, allowing in many situations a good compromise between farmer income, productivity, food quality and the conservation of natural resources [2,3], and thus, an important agribusiness for farmers, owing to the premium returns from organic products [4]. Although the problem of food production is too complex to be solved exclusively through the production model, in some situations OF can be a part of the solution. In fact, OF not only has the potential to trigger rural development, but also to respond to the concerns and demands of modern society regarding food security and safety, and the social and environmental role of agricultural systems, which has been witnessed worldwide, for example in Iran [5], Syria [6], and Europe [7]. OF can also meet the mitigation measures imposed upon agriculture by climate change emergencies, through practices such as tillage, composting, soil carbon sequestration, and energy offsets [8,9]. Other examples of circular economy with environmental benefits include the nutrients recycling of agricultural wastes and by-products, as well as the use of local and renewable energy sources [10,11].

One of the most difficult agronomic aspects of $\mathrm{OF}$ is crop protection, given the restrictions upon the use of most synthetic pesticides. Regarding weeds, the usual OF practices for effective control often use a combination of (i) mechanical control, (ii) crop rotation, to reduce weed potential [12], (iii) application of bio-herbicide products [13], and (iv) flaming [14]. Solutions for pests and diseases control should only resort to pesticides and genetically resistant varieties authorized by official entities, for example the European Union (EU) $[15,16]$. A feature of this production mode, compared to the conventional one, is lower production efficiency, higher cost and higher labor requirements, resulting in an increased risk level, which can surpass the yield incomes of OF products.

Soil fertility maintenance is ensured through the use of certified organic fertilizers and slow acting minerals [17,18], which provide sustainable nutrient cycles [19], being particularly valued those derived from composting residues or by-products from agricultural, livestock, industrial or forestry activities. Soil conservation maintaining high levels of organic matter and organic-based nitrogen relies on the use of green manure and winding, and on biological nitrogen fixation [1]. Composting, using organic remains not only feeds the soil and the most demanding crops, but also reduces the impacts of waste disposal, improves soil quality and minimizes soil losses and allows carbon sequestration. Thus, soil management on OF systems can have considerable and positive effects on the control of greenhouse gas (GHG) emissions [10] and plays a key role in the conservation of fertility and biological biodiversity, beyond the productivity itself [20].

Cultivation is another aspect that requires changes from conventional practices. Conservation tillage techniques are very important in OF [21], as well as some practical issues [22], allowing, among other advantages, the increase of phosphorus availability and soil nitrogen content [23]. The choice of varieties is a criterion to be considered for better fertilization efficiency, as exemplified by [24] for rice. Crops rotation is used to better harness soil nutrient capacity and also to prevent phytosanitary problems and, consequently, decreasing pesticide needs [1]. Mulching could be effective suppressing weeds, when retained on the soil surface [25], and at the same time, providing organic matter to the soil. Flaming and cultivation, despite being effective tools when used together, should be considered as two of the many tools in the toolbox of integrated weed management [14]. Precision agriculture technologies, such as robotic weeding and band steaming for weed management, could contribute to efforts to cope with pests and weed management, also reducing the labor demand [26].

Europe has 14.6 million hectares of OF [27], and the European policy is encouraging OF expansion [28], in parallel with an increasing demand for organic products fulfilling effective certification standards [29,30], although there are several conditioning factors, like economic or crop protection [31]. There are many examples of higher profitability in OF than in conventional farming, despite the fact that the former exhibits a reduction in physical yields, and it is offset with the higher appreciation and valorization of the market [32-37]. 
In Portugal, there are three governmental action plans: the National Strategy for Organic Farming [38], the Action Plan for the Production and Promotion of Organic Products [39], and the National Strategy for Green Public Procurement 2020 [40], demonstrating the relevance given to $\mathrm{OF}$, and the feasibility in various productive areas of agriculture and livestock. The OF enables stimulation of agricultural activity, as it allows the supply of highly valued new products to the market, boosting regional economic activity and rural development. OF can also take advantage of the development dynamics promoted by the development of irrigated land in Portugal [41], especially since the most profitable crops are irrigated. In addition, in areas of minifundium, or smallholding farms, the intensification of production is crucial for reasons of farm economic profitability. Therefore, the promotion of OF in Portugal needs the mitigation of the main weaknesses of this production mode, identified by the Portuguese Government [39]: (i) the difficulty in the supply of national organic products to accompany the growth of domestic demand, with the consequent increase in imports; (ii) insufficient production factors for OF (fertilizers, phytopharmaceuticals, seeds) available at high prices, associated with scarce information; (iii) lack of infrastructures to enable the supply concentration; (iv) insufficient organization of producers, which is reflected in weak negotiating strength and difficulties in regulating the market, in case of seasonal surpluses; (v) low representation of the $\mathrm{OF}$ in the usable agricultural area; (vi) weak organic livestock production and insufficient slaughtering capacity; (vii) lack of qualified professionals and offers of research and development (R\&D); (viii) very high prices of organic foods for consumer; (ix) weak investment by the economic agents in concerting marketing strategies; $(x)$ insufficient technical ministerial structure dedicated to organic production, which is reflected in the lack of statistical data on this sector.

The expectation of OF profitability in small family farming, supported by the successful examples previously mentioned worldwide, led to the development of the present study, applied to the Lis Valley Irrigation District. It addresses the issue of conversion from conventional to $\mathrm{OF}$, including choosing and evaluating the most appropriate technologies, the productive paradigm change process, and the way farmers act and decide. This research objective is the assessment of constraining factors on OF expansion and outline the procedures for the acquisition of technical knowledge, the adaptation of technologies, the support for the conversion of production models, and the specialized training of farmers for this action.

\section{Materials and Methods}

\subsection{Study Area}

The study area is located in the Lis Valley Irrigation District (LVID), which is a public irrigation district, located in the Coastal Center of Portugal (coordinates 39 51'22.1" N 8 50'56.1" W), belonging to the Leiria Administrative District (Figure 1), and managed by the LVID Water User's Association. The total area is about 2000 ha, mainly with modern alluvial soils of high agricultural quality, although some have poor drainage conditions. The main crops grown in the LVID include forage maize, forage grass, horticultural, orchards and rice [42]. 


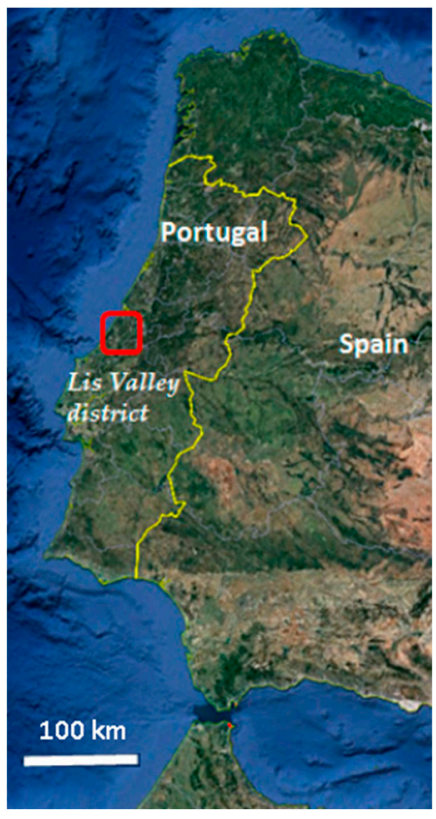

(a)

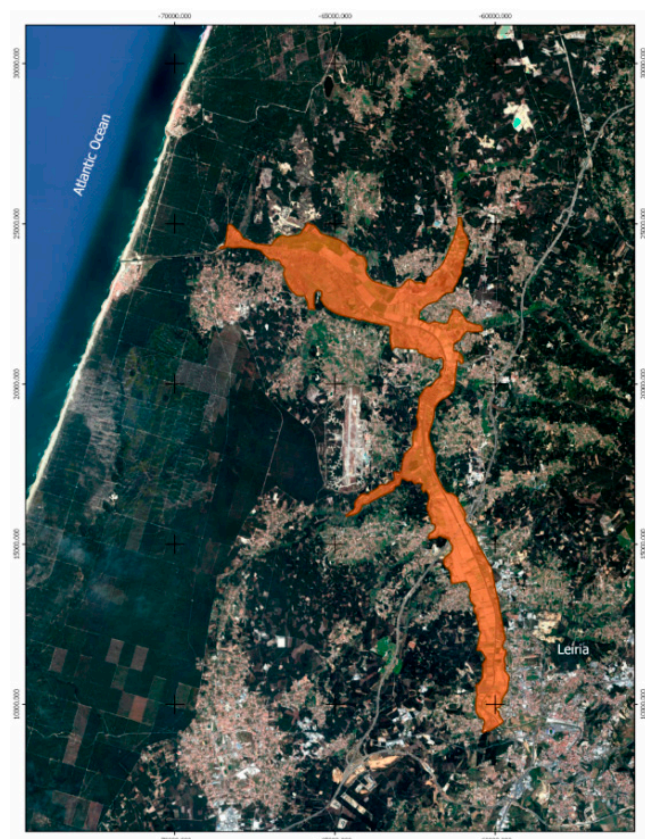

(b)

Figure 1. Location of the Lis Valley Irrigation District in Portugal (a), and in the center region (b). (source: Google Maps, https://maps.google.pt).

The predominant climate in the Lis River watershed results from Mediterranean and Atlantic influences. The Mediterranean influence is reflected mainly in summer, as a result of the high temperatures and sunshine and the absence of precipitation. The Atlantic influence is characterized by the predominant winter front surfaces which, moving from west to east, are responsible for most of the precipitation. A hot summer with virtually no rainfall is opposed to a winter with mild temperatures but very rainy (Figure 2). Annual average temperature is $15.9^{\circ} \mathrm{C}$ and annual average precipitation is $790 \mathrm{~mm}$. According to the Köppen climate classification, the climate in the LVID is Cbs type and is characterized essentially by temperate and mild summers and winters with mild temperatures. Rainfall is concentrated mainly from October to March and its average values decrease from the headwaters of the Lis Valley basin towards the coastal region [43].

A particular feature of this study area is a high heterogeneity regarding the field parcels size and their spatial distribution. The structure of the on-farm parcels property is characterized by a majority of small parcels, with an average of 0.20 ha (Table 1), this aspect being an effective constraint to the field irrigation modernization and agriculture development and sustainability. This problem is being mitigated through an informal reparcelling of the fields carried out by farmers, through renting the properties [44].

Table 1. Number of parcels per area classes in the LVID.

\begin{tabular}{ccc}
\hline Area Classes (ha) & Number of Parcels & $\%$ \\
\hline below 0.1 & 4157 & 39.1 \\
$0.1-0.5$ & 5909 & 55.5 \\
$0.5-1.0$ & 402 & 3.78 \\
$1.0-5.0$ & 163 & 1.53 \\
$5.0-20$ & 6 & 0.06 \\
above 20 & 2 & 0.02 \\
\hline Total & 10,639 & 100 \\
\hline
\end{tabular}

Source: [42]. 


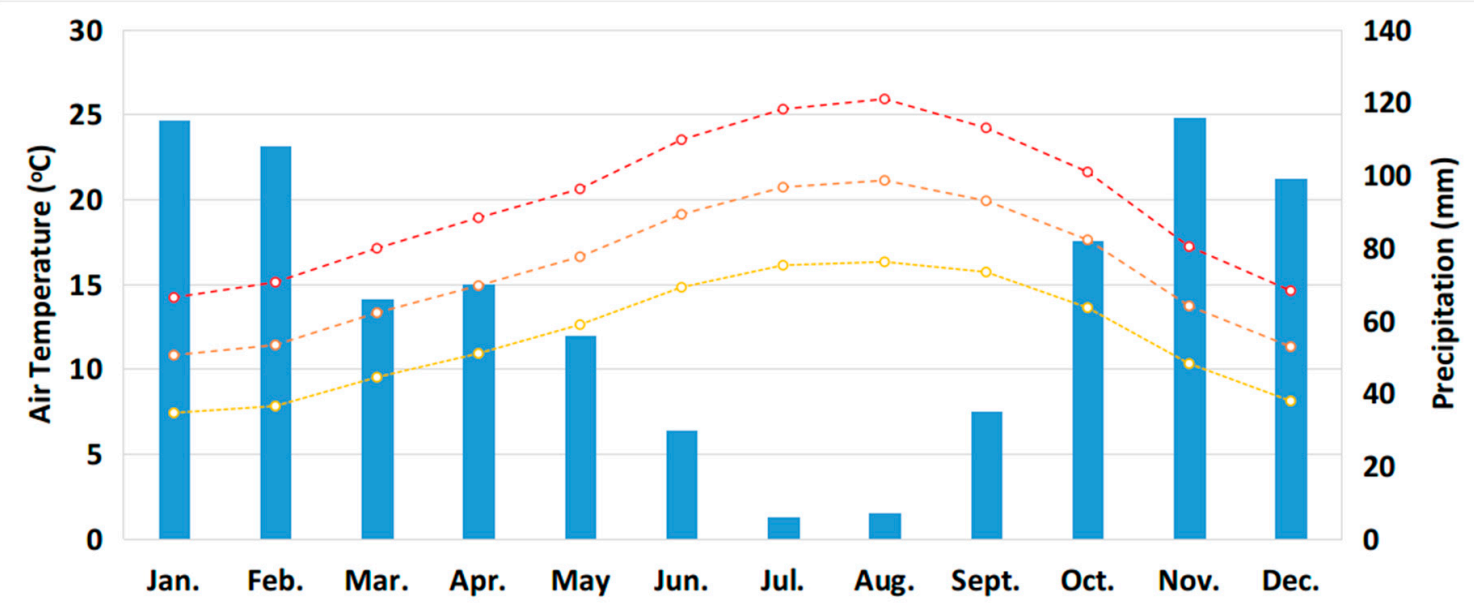

Figure 2. Monthly average climatic data for Leiria region (adapted from [45]); Precipitation (blue) and Maximum (red), Average (orange) and Minimum Temperature (yellow).

Since 2011, Portuguese exports of vegetables, plants, roots and tubers have had sustainable growth of $11 \%$ per year, that growth being in the Central Region of $14 \%$, and in the Leiria district of $10 \%$; however, it fluctuates over the period analyzed [46]. Edible vegetables, plants, roots and tubers accounted for $23 \%$ of plant exports; the Central Region, in 2017, represented $29 \%$ of national horticultural exports and the Leiria region $2 \%$. Therefore, a high export potential for vegetables can be expected, making it worth investing in vegetable production in the LVID, as the fruit and vegetable sector grew 23\% between 2016 and 2017, representing around 937 million euros in 2017 [46].

\subsection{Assessing the Constraint Factors to Adopting Organic Farming}

The methodology to assess the constraint factors for OF expansion in the LVID was based on inquires directed to farmers. For this purpose, a questionnaire was developed to obtain the following information: sociodemographic data, relevance and motivation of agricultural activity, ownership and exploitation of field parcels, markets and productions, willingness to adopt $\mathrm{OF}$ and corresponding required support (Appendix A). Landowner surveys were conducted by interview in person, after a prior contact with respondents, from March to April 2019.

The particular aspects of land characteristics were considered for the inquiry design. As the inquires covered the owners of farms, composed of field parcels, their initial pre-characterization was required in order to plan the choice of samples. The area of each parcel was obtained from the land registry by the LVID Water User's Association, which allowed the total area owned by each farmer to be determined. The stratification of farms according to their areas was required due their non-uniformity (dominance of the smaller ones). This resulted in three classes: (i) farms with areas larger than $8.5 \mathrm{ha}$, hereinafter referred to as "Large"; (ii) farms with areas smaller than $25 \mathrm{~m}^{2}$, designated as "Small", and (iii) farms with intermediate area, generally with areas lower than 2 ha, referred to as "Medium". The size of samples per class was determined through a statistical analysis performed according to the normal distribution [47]. Thus, about 20 owners per class were selected for the interview.

The collected data were analyzed using the IBM SPSS Statistics 25.0 software. To evaluate the strength of the association between the analyzed variables (farm size, age, gender, relevance of agricultural activity, educational level, production destination, sales channels, type of market, willingness to adopt OF), Pearson coefficient correlation ( $r$ ) was used when those variables followed a normal distribution, and the Spearman coefficient $(\varrho)$ otherwise, since it is not sensitive to the distribution asymmetry [47-49]. 


\section{Results}

\subsection{The Farmers: Social Features, and Attitudes Regarding Agricultural Activity}

The sociodemographic data of respondents (class age, gender and educational attainment frequencies and farm size class) are synthetized in Table 2 and Figure 3. Most respondents are over 50 years old $(75.5 \%), 35.1 \%$ of whom are over 65 years old, that applies for both genders. The majority $(84.2 \%)$ are males (Table 2$)$. It is worth highlighting the low level of education (54.4\% only attended up to the 4th grade), which is associated with the high age group of respondents, i.e., about $35 \%$ of respondents were more than 65 years old (Figure 3). These figures are lower than those obtained from the Farm Structure Survey [50], held in 2017, which found out that $54.6 \%$ of the individuals were over 65 years old. However, these values are in accordance with the 2009 Agricultural Census [51], regarding the characterization of the agricultural producer: "type agricultural producer is male, he is 63 years old" and "only completed the 1st cycle of basic education".

Table 2. Relative frequency (\%) of age and gender of respondents by the farm size.

\begin{tabular}{ccccccccccccc}
\hline $\begin{array}{c}\text { Age } \\
\text { (Years }\end{array}$ & \multicolumn{4}{c}{ Total of Farmers } & \multicolumn{4}{c}{ Male Gender } & \multicolumn{3}{c}{ Female Gender } \\
\cline { 2 - 13 } Old) & $\mathbf{S ~}^{\mathbf{1}}$ & $\mathbf{M}^{\mathbf{1}}$ & $\mathbf{L}^{\mathbf{1}}$ & Total & $\mathbf{S}$ & $\mathbf{M}$ & $\mathbf{L}$ & Total & $\mathbf{S}$ & $\mathbf{M}$ & L & Total \\
\hline $20-40$ & 5.0 & 23.8 & 12.5 & 14.0 & 2.1 & 10.4 & 4.2 & 16.7 & 0.0 & 0.0 & 0.0 & 0.0 \\
$41-49$ & 0.0 & 19.0 & 12.5 & 10.5 & 0.0 & 6.3 & 2.1 & 8.3 & 0.0 & 11.1 & 0.0 & 11.1 \\
$50-64$ & 35.0 & 38.1 & 50.0 & 40.4 & 12.5 & 14.6 & 12.5 & 39.6 & 11.1 & 11.1 & 33.3 & 55.6 \\
above 65 & 60.0 & 19.0 & 25.0 & 35.1 & 20.8 & 6.3 & 8.3 & 35.4 & 22.2 & 11.1 & 0.0 & 33.3 \\
\hline \multicolumn{4}{c}{ 'Farm size: S, Small (lower than $25 \mathrm{~m}^{2}$ ); M, Medium; L, Large (over 8.5 ha). }
\end{tabular}

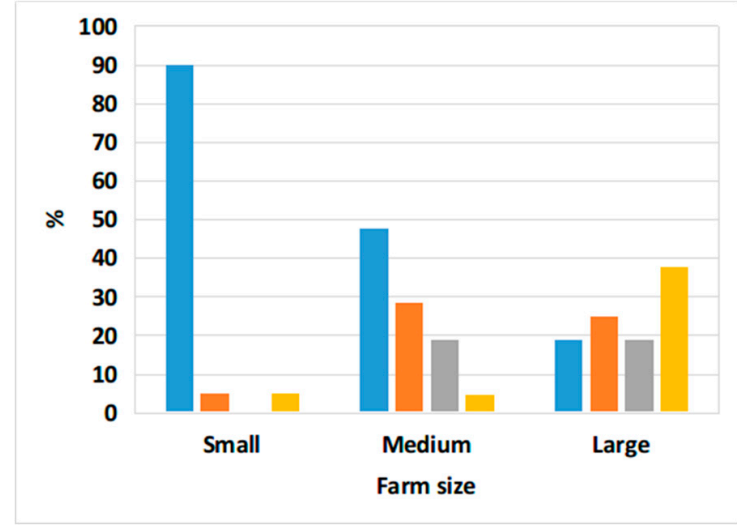

(a)

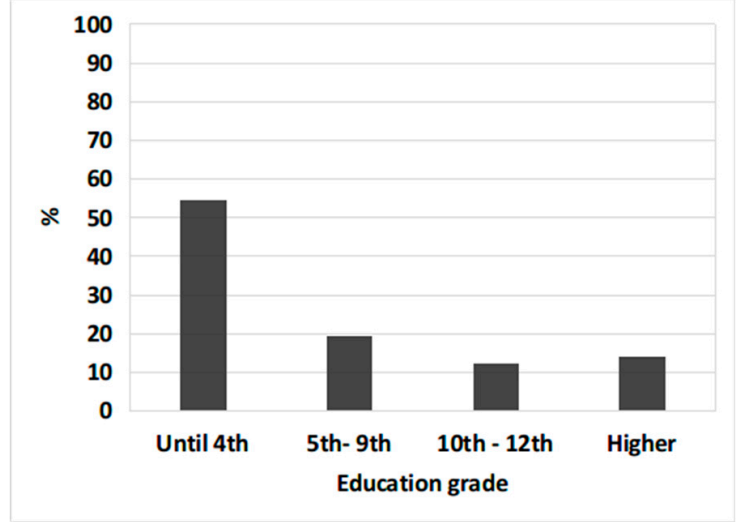

(b)

Figure 3. Relative frequency (\%) of educational level of respondents by: (a) the farm size (Until the 4th grade, blue; 5-9th grade, orange; 10-12th grade, grey; Higher education, yellow), and (b) the overall responses. Farm size: Small (lower than $25 \mathrm{~m}^{2}$ ), Medium, Large (over $8.5 \mathrm{ha}$ ).

Agricultural activity plays a secondary role for more than half of respondents (57.9\%). The income earned allows the farmers to add extra gain to the main activity because they rent their parcels or have another activity in a different economical sector. "Not relevant" answers include landowners who farm for self-consumption or choose not to cultivate the fields. Most smallholders considered the agricultural activity as a secondary role (Figure 4). This confirms the importance of family farming in Portugal and the self-consumption of the agricultural structure [52]. There is a weak positive correlation ( $5 \%$ significance level) between the relevance of agricultural activity and the farm size classification $(\mathrm{r}=0.301 ; \varrho=0.328)$. As the size of the farms decreases, agricultural activity loses relevance as the main activity and becomes a secondary one. 


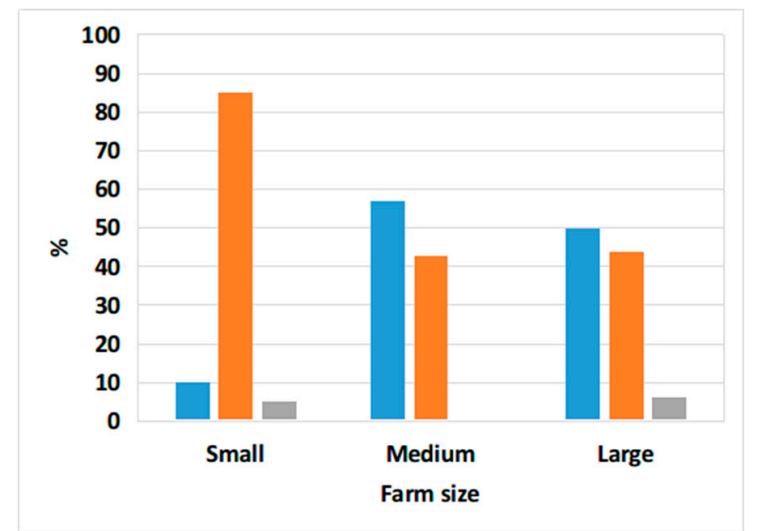

(a)

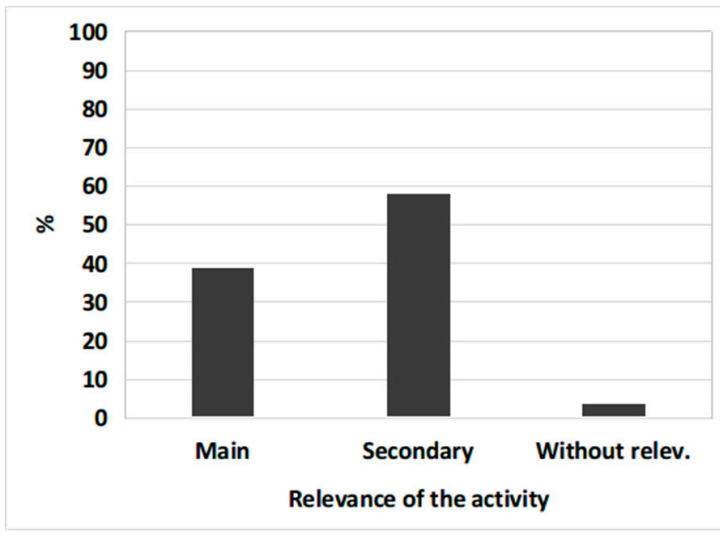

(b)

Figure 4. Relative frequency (\%) of relevance of agricultural activity of respondents by: (a) the farm size (Main activity and source of income, blue; Secondary activity that supports family income, orange; Without relevance, grey), and (b) the overall responses. Farm size: Small (lower than $25 \mathrm{~m}^{2}$ ), Medium, Large (over $8.5 \mathrm{ha}$ ).

The farmers' motivation for the practice of agriculture is mainly explained (in $73 \%$ of the responses) by the combination of several factors: (i) it is a family activity ( $30 \%$ of the answers); (ii) the owner has the possibility to continue a business that already existed in the family; (iii) the existence of land, inherited or acquired, that is intended to be monetized; (iv) they are landlords who rent the parcels, and the benefit they get from the land is the financial income and not the agricultural activity itself; and (v) the family farming encompasses elements associated with family values, such as solidarity, continuity and commitment. These results revealed that family farming is identified with entrepreneurial skills, ownership and risky behavior, resilience and individual achievement. Regardless of the size of the agricultural enterprise, the prevalence of family-ownership in the Lis Valley is a potential factor for the continuity of future agriculture, because of the skills provided in situ to the next generations, as referred to by other studies [53,54].

\subsection{The Farms: Ownership, Exploitation and Markets}

Results regarding the land possession and exploitation of the parcels show the following agrarian structure: owner and farmer, 54.4\%; owner and not farmer, $19.3 \%$; loan (free installment loan) and farmer, $10.5 \%$; landlord and lessee, $14.0 \%$; and owner and lending, $1.8 \%$. In the context of land tenure, the use of the parcels is as follows: (i) $78.2 \%$ are cultivated by the owner; (ii) $12.7 \%$ are rented; (iii) $5.5 \%$ are partially cultivated by the landlord and leased; and (iv) $3.6 \%$ left as fallow. Landlords want to maintain land tenure in the future, as it is currently an issue of critical concern.

Renting land has a great tradition in the LVID. The reasons pointed out by landlords for renting their parcels include: (i) they do not want to sell the fields, because they have heirs to inherit the land; (ii) the selling price offered does not please them; (iii) they have a great emotional attachment to the land; (iv) they have other activities and sources of income; (v) there is a feeling that the land is a guarantee for the future; and, lastly, (vi) they do not need the money from the sale.

The tenant's reasons for renting the parcels comprehend: (i) difficulties in paying the price set by the seller; (ii) renting has become a form of traditional land use and they do not feel the need to own the property; (iii) they have other activities besides agriculture, which is a secondary one, and so do not feel stability for ownership; (iv) there is a strong variability in the choice of crop and productivity, and the renting provides greater freedom to choose the parcels than their ownership; (v) the difficulty of obtaining manual labor, especially in horticulture, (vi) constraints about the area to be cultivated, since it is sized according to the staff; (vii) it is easier to detach from the land, avoiding it becoming a burden, if agriculture becomes unprofitable; and (vii) agriculture requires a lot of physical effort. 
The 19.3\% figure of "pure" renting, excluding the combined renting and ownership, clearly denote the impact of this form of exploitation of the parcels.

The results of the surveys about the destination of production, related to farm size and age, are presented in Table 3. Among landowners or tenants there is no predominant answer regarding the yield fate in relation to the other groups, because the intermediate scenario of "selling one part of production, the other being for own consumption" mitigates the difference that exists between sales of all production (43.5\%) and production for self-consumption (32.6\%). The correlation between the destination of production and the size of the holdings is weak positive ( $5 \%$ significance level) $(r=$ $0.282 ; \varrho=0.314)$. As the size of the farms becomes smaller, production tends to be for self-consumption. There is also an average positive correlation between age and production destination, with significance at the $5 \%$ level $(r=0.433 ; \varrho=0.432)$, as older farmers tend to produce for self-consumption $(19 \%$ of variation in production destination is explained by age).

Table 3. Relative frequency (\%) of production destination by relevance of agricultural activity, farm size, and age of respondents.

\begin{tabular}{cccccccccccc}
\hline \multirow{2}{*}{$\begin{array}{c}\text { Destination of the } \\
\text { Production }\end{array}$} & \multirow{2}{*}{ Total } & \multicolumn{3}{c}{ Relev. Activity } & \multicolumn{3}{c}{ Farm Size $^{\mathbf{2}}$} & \multicolumn{4}{c}{ Farmer Age (Years Old) } \\
\cline { 3 - 12 } & & Ma. & Sec. & WR & S & M & L & $\mathbf{2 0 - 4 0}$ & $\mathbf{4 1 - 4 9}$ & $\mathbf{5 0 - 6 4}$ & $\geq \mathbf{6 5}$ \\
\hline Market only & 43.5 & 76.2 & 16.7 & 0.0 & 16.7 & 70.6 & 45.5 & 83.3 & 75.0 & 44.4 & 22.2 \\
Partly to market & 23.9 & 19.0 & 29.2 & 0.0 & 27.8 & 23.5 & 18.2 & 16.7 & 0.0 & 27.8 & 27.8 \\
Self-consumption & 32.6 & 4.8 & 54.2 & 100 & 55.6 & 5.9 & 36.4 & 0.0 & 25.0 & 27.8 & 50.0 \\
\hline
\end{tabular}

${ }^{1}$ Relevance of activity: Ma., Main; Sec., Secondary; WR, Without relevance. ${ }^{2}$ Farm size: S, Small (lower than $25 \mathrm{~m}^{2}$ );

M, Medium; L, Large (over 8.5 ha).

The analysis of results of the destination of production related to the relevance of the owners' activity, show that those who have their main activity in agriculture sell all production, and conversely, in the secondary level, production is mainly for self-consumption (Table 3). There is a significant positive correlation between these parameters ( $1 \%$ of significance level) $(r=0.646 ; \varrho=0.651)$, where $42 \%$ of the variation in the destination of production is explained by the relevance of agricultural activity.

Sales channels and type of market were also questioned, and the results are shown in Table 4 . Owners were asked to choose the two main sales channels, referring to whether they correspond to the domestic, foreign market, or both. Most farmers (77\%) sell directly to the final domestic consumer, and no one sells exclusively to foreign markets. Therefore, it can be concluded that in the Lis Valley short supply chains predominate. It is important to note that sales to large retailers do not exist, which may be due either to the low production values, not justifying this choice; or, to the selling price for this channel, which will not compensate, compared to alternative marketing channels. It would be important to further analyze the specific relationship of marketing channels with OF.

Table 4. Relative frequency (\%) of sales channels by type of market.

\begin{tabular}{cccc}
\hline Sales Channels & Only Domestic Markets & Domestic and Foreign Markets & Total \\
\hline Final consumer & 73.3 & 80.0 & 77.1 \\
Small retailers & 10.0 & 20.0 & 11.4 \\
Cooperatives or wholesalers & 13.3 & 0.0 & 8.6 \\
Large surfaces & 0.0 & 0.0 & 0.0 \\
Other producers & 3.3 & 0.0 & 2.9 \\
\hline
\end{tabular}

\subsection{Main Limiting Factors for Organic Farming Expansion}

One crucial aspect of the results is that most of the respondents $(84 \%)$ were not interested in switching to $\mathrm{OF}$, regardless of the farm size classes they belong to, although this resistance is higher in smaller sized farmers than in medium and larger ones (Figure 5). The main farmers decision factor (Table 5) that determine the changing to OF is the public support (57.6\%), particularly required during the conversion period. The other relevant factors are related with the market, through higher 
production prices $(20.3 \%)$, and the guarantee of outlets $(15.3 \%)$. The farmers with an affirmative willingness to adopt $\mathrm{OF}$ valued these two market factors.

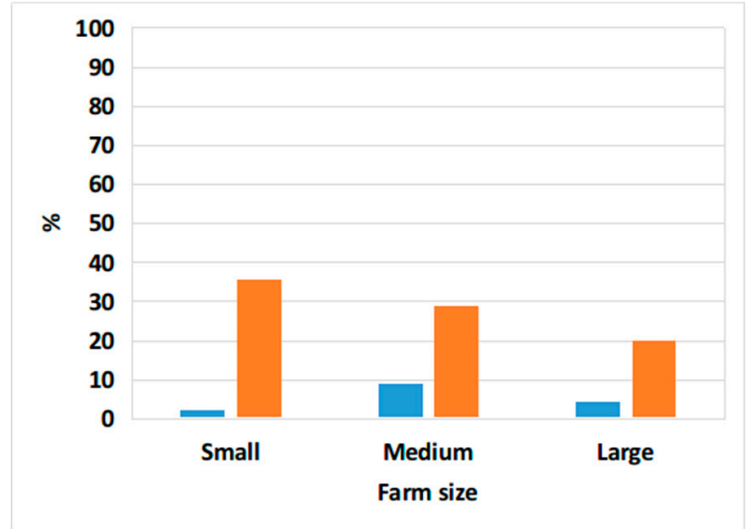

(a)

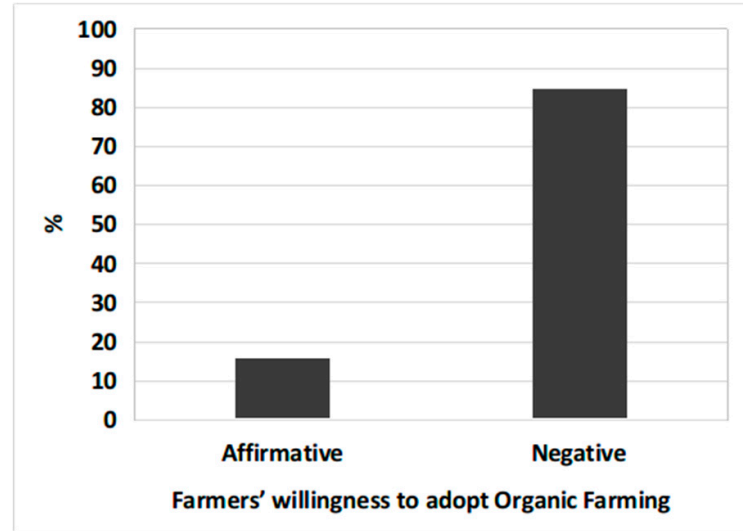

(b)

Figure 5. Relative frequency (\%) of farmers' willingness to adopt Organic Farming by: (a) the farm size, (Affirmative, blue; Negative, orange), and (b) the overall responses. Farm size: Small (lower than $25 \mathrm{~m}^{2}$ ), Medium, Large (over $8.5 \mathrm{ha}$ ).

Table 5. Relative frequency (\%) of main decision factors governing farmers' willingness to adopt organic farming, by farm size.

\begin{tabular}{ccccccccc}
\hline & \multicolumn{2}{c}{ Small Farms } & \multicolumn{2}{c}{ Medium Farms } & \multicolumn{2}{c}{ Large Farms } & \multirow{2}{*}{ Total } \\
\cline { 1 - 6 } Main Decision Factors & $\mathbf{A}^{\mathbf{1}}$ & $\mathbf{~ N}^{\mathbf{1}}$ & $\mathbf{A}$ & $\mathbf{N}$ & $\mathbf{A}$ & $\mathbf{N}$ & \\
\hline Public support & 0 & 13.6 & 1.7 & 18.6 & 0 & 23.7 & 57.6 \\
Assurance of market outlets & 3.4 & 1.7 & 5.1 & 3.4 & 0 & 1.7 & 15.3 \\
Market prices & 3.4 & 1.7 & 6.8 & 5.1 & 1.7 & 1.7 & 20.3 \\
Expand cultivated area & 0 & 0 & 1.7 & 1.7 & 0 & 3.4 & 6.8
\end{tabular}

\footnotetext{
${ }^{1}$ A, affirmative; $\mathrm{N}$, negative farmers' willingness to adopt OF. Farm size: Small (lower than $25 \mathrm{~m}^{2}$ ), Medium, Large
} (over 8.5 ha).

It should be noted that, presently, farmers produce quality agri-food products in integrated mode, subject to certification. This system aims at sustainable agriculture through the adoption of good agricultural practices, including crop protection methods, while mitigating risks to human health and the environment, with the least possible disruption to agricultural ecosystems [55]. The possibility of adopting OF implies a new certification and compliance with stricter rules on the use of production factors, a situation that contributes to the attitude that is averse to change.

The farmers willing to convert to OF highlighted the following keywords: the price; incentives; the benefit to the health of living beings and the environment; and the ease of change due to the size of the parcels. In turn, those who had negative answers, referred to: production for animal feed; small yield; reduced size of parcels; consumer non-differentiation between different modes of production; constraints of application of pesticides; low productivity of OF yield; perception of cross-contamination between parcels and the environment; and low availability of manual labor required by the OF.

Finally, results allow concluding that the main factors limiting the choice for OF conversion were: (i) size of the fields-due to their small size and discontinuity, which makes OF certification difficult, as it limits the application of ecological lanes and corridors, mechanization, and affects the risk of cross contamination; (ii) forage production-being intended for animal feed; note that products of animal origin imply a complex certification, obliging the certification of the whole agri-food chain, therefore making OF forage unappealing; (iii) markets—considering that $77 \%$ of respondents sell to the final consumer and about $81 \%$ sell to the domestic market (e.g., to the small local retail or directly to the consumer in the so-called short chains), they do not feel the need to convert to another mode 
of farming because the consumer would not overvalue the OF product; (iv) farmers' age-as age progresses, the farmers become more averse to change, favoring young and better-educated farmers. In conclusion, OF has significant potential for stimulating rural development in the Lis Valley and the efforts and resources of the various stakeholders need to be harmonized to deliver effective support to farmers.

\section{Discussion}

The results obtained in this study relative to the LVID concerning the land, demographic and socioeconomic characteristics highlight a number of difficulties in relation to agricultural modernization and the adoption of OF. The constraints to OF development, mainly related to the land and social profiles, include: (i) the land structure of the farms, such as the small sized parcels and their geographical dispersion, or the small-sized farms; (ii) the land use, by the landowner or by the lessee, that affects their prospect to make long term investments; and (iii) the age and training of farmers, which impacts their predisposition to adopt more advanced and complex technologies, or to take greater risks. Land ownership is a fundamental issue, because it hinders long-term OF investments, and also the predisposition for the conversion to $\mathrm{OF}$, given the return uncertainty. In fact, the legal requirement of a minimum of three years conversion time for certification of OF vegetables [55], makes the profitability of this transition period crucial.

The major number of fields (78\%) of the LVID are cultivated by the owners, which in itself is a good indicator. The fact that the landowners cultivate the land is an important aspect. However, the smallholding situation with very small fields (see Table 1), being $94.6 \%$ of the fields lower than $0.5 \mathrm{ha}$, results in very strong constraints on development. There are several reports (e.g., Murray and McGrath [56], Ruhf and Wagner [57]) of studies carried out on the issues of investment, land cost, land ownership, and return on investment related to land valuation. Regarding land ownership and the barriers to sustainable agriculture, Carolan et al. [58] concluded that the tenant uncertainty is a barrier to sustainable agriculture and that joint work between landowners and tenants is required to reduce that uncertainty and ensure continued investment. Ciaian et al. [59] point out that, although the sale value of agricultural land is higher than the lease value, sales are encouraged due to the security investment they convey, because transferring all property rights to the new owner allows easier access to credit, as land can be given as collateral. In most European Union (EU) countries, the rental market appears to be more important than the sales market and a large part of the agricultural area is leased. According to Ciaian and co-authors [59], Portugal in 2007 had one of the lowest leased land rates in $\mathrm{EU}$, under $25 \%$ of the used agricultural area (UAA). The positive influence of age and education on entrepreneurship in $\mathrm{OF}$ is a central issue, where generational renewal plays a particularly important role for innovation and development [60]. Younger farmers with higher academic and agricultural background have more resources to manage new technologies and deal with the most demanding market competition contexts, creating new development models around the OF concept, based on shared projects with related topics, such as the green and circular economy [61,62].

The LVID farmers marked a clearly negative predisposition to the adoption of OF where the main factor was the problem of insufficient public support (Table 5, 58\% of responses), relevant in the conversion period required by the certification process. Therefore, all public actions that facilitate the conversion phase will have a significant effect on promoting OF, through farmers' decisions with their consequent multiple benefits on rural development and food security.

Certification is the procedure to guarantee compliance with obligations under the law safeguarding the achievement of the OF objectives [63], and it has gained increasing attention worldwide, being essential to provide a safe assurance to the market of the compliance with OF principles and standards [64]. The somewhat complex process of obtaining certification includes many challenges ahead and the process in itself affects the decision to convert a conventional farm [65]. There are several examples that demonstrate these difficulties, like in Spain [37], or in Germany [66]. Before starting the OF activity, the farmer must prepare a preliminary assessment to identify the contamination risky 
areas, the historical context of fertilization and pesticides, and to perform chemical analyzes to the soil and water. The transition period until the OF certification will depend on the actual soil and water conditions, and the type of crops grown. In general, this period takes, at least, three years. This lag time has significant costs to be supported by the farmer, due to loss of yield and uncertainty about conversion efficiency. This microeconomic framework explains the need for public support for this process, justified to compensate for this inevitable loss of farm income.

Results of these studies also showed that marketing is a main decision factor (vd. Figure 5, assurance of market outlets, plus market prices, correspond to $35.6 \%$ ), and highlighted the importance of short marketing circuits to solve this issue. On the other hand, the role of small family farming also promotes the OF feasibility because it facilitates access to local markets for greater flexibility and smaller size. The organization of production is a very important aspect for the OF viability and competitiveness [67]. The characteristics of family farming give them special aptitude for OF, namely for vegetables production, due to their labor flexibility and availability $[68,69]$. The Portuguese government considered small family farming very important to the OF development, due to their weight in terms of national number of farms (242.5 thousand farms, $94 \%$ of total), using $54 \%$ of utilized agricultural area (UAA) and $80 \%$ of total agricultural labor [70]. The Family Farming Statute emphasized the need to support the creation of proximity markets and short circuits and the creation of a specific public procurement regime for proximity agrifood products [52]. Family farms can exploit the opportunity of short circuits that demonstrate social, economic, and environmental advantages [71,72], especially in the EU, although the results depend to a great extent on each situation [73]. Gonçalves [74] reported the high potential for OF of small family farming with a positive impact on the development of the traditional irrigation systems in the Center and North of Portugal, by linking agriculture with landscape, environment, and nature conservation, and by valuing specific agricultural products, such as aromatic and medicinal plants, through the economic activity of rural tourism and regional cuisine.

A comparative analysis of the OF practice in Portugal and in other European countries, namely Spain, Italy and Greece, also in a Mediterranean climate, and in the Czech Republic, with a different temperate-continental climate, based on published statistical data, is presented in Table 6 . In the EU, 11.9 million ha are occupied with $\mathrm{OF}, 61 \%$ of which with the dominant crop, pastures and forages for biological livestock. The importance of these crops varies significantly from the Czech Republic $(84.2 \%)$ to Italy $(27.6 \%)$. In Portugal, the permanent pastures and forage crops occupy $58.3 \%$ of the OF production area, mainly located in the Southern continental region and in Azores Island. Conversely, the representativeness of vegetable crops per country is much smaller, almost without expression in the Czech Republic ( $0.1 \%)$ to an area over 60,000 hectares in Italy (2.6\%). Greece, Portugal and Spain $(0.5 \%$ to $0.7 \%$ ) all together grow these types of crop in 27,251 ha. It is worth noting that in Greece, olive and vineyard crops, although with little expression in the cultivated area, show significant profitability [75].

Table 6. Organic farming statistics of five European countries (Portugal, Spain, Italy, Greece, Czech Republic) regarding the cultivated area (all crops, permanent grassland, fresh vegetables); farm area; farmer's age and market.

\begin{tabular}{|c|c|c|c|c|c|c|c|c|c|c|c|}
\hline \multirow{3}{*}{ Country } & \multicolumn{8}{|c|}{ Area of Organic Farming } & \multirow{3}{*}{$\begin{array}{c}\text { Farmers } \\
\text { Below } 35 \\
\text { Years Old }{ }^{4} \\
\%{ }^{d}\end{array}$} & \multicolumn{2}{|c|}{ OF Market } \\
\hline & \multicolumn{2}{|c|}{ All Crops ${ }^{1}$} & \multicolumn{2}{|c|}{$\begin{array}{l}\text { Permanent } \\
\text { Grassland }^{1}\end{array}$} & \multicolumn{2}{|c|}{$\begin{array}{c}\text { Fresh } \\
\text { Vegetables }\end{array}$} & \multirow{2}{*}{$\begin{array}{c}\text { Farm } \\
\text { Average }^{3}\end{array}$} & \multirow{2}{*}{$\begin{array}{c}\begin{array}{c}\text { Farms } \\
<2 \text { ha }\end{array} \\
\%^{c}\end{array}$} & & \multirow{2}{*}{$\begin{array}{c}\begin{array}{c}\text { Spending } \\
\text { Per Person }\end{array} \\
€^{\mathrm{e}}\end{array}$} & \multirow{2}{*}{$\begin{array}{c}\text { Organic } \\
\text { Share }^{1} \\
\%{ }^{\mathrm{f}}\end{array}$} \\
\hline & ha & $\%^{a}$ & $\mathrm{Ha}$ & $\%^{b}$ & ha & $\%^{b}$ & & & & & \\
\hline Portugal & 253,786 & 7.0 & 147,323 & 58.3 & 3276 & 0.7 & 110 & 46.1 & 0.2 & 2 & 0.2 \\
\hline Spain & $2,083,173$ & 8.9 & $1,085,338$ & 52.8 & 22,105 & 0.7 & 62 & 26.3 & 1.3 & 42 & 2.8 \\
\hline Italy & $1,908,653$ & 15.4 & 544,048 & 27.6 & 60,732 & 2.6 & 50 & 27.5 & 2.1 & 52 & 3.2 \\
\hline Greece & 410,140 & 5.0 & 200,663 & 55.9 & 1870 & 0.5 & 7.5 & 50.6 & nd & 6 & nd \\
\hline Czech Rep. & 520,032 & 12.2 & 424,090 & 84.2 & 260 & 0.1 & 180 & 10.3 & nd & 9 & 0.9 \\
\hline
\end{tabular}

OF, Organic Farming; ${ }^{a}$ Relative to the total agricultural area; ${ }^{b}$ Relative to the total OF area; ${ }^{\mathrm{c}}$ Relative to the total number of OF farms; ${ }^{\mathrm{d}}$ Relative to the total number of farmers in OF mode; ${ }^{\mathrm{e}}$ Euros per capita, per year; ${ }^{\mathrm{f}}$ Relative to all food and drinks sold per year; Data source: ${ }^{1}$ [27] (2017 data); ${ }^{2}$ [77] (2018 data); ${ }^{3}$ [76] (2015 data); ${ }^{4}$ [78] (2000 data); nd, no data available. 
In these countries, the average area per farm surpasses 50 ha, except in Greece. In fact, there is a tremendous variability in the farms size, from 7.5 ha in Greece to 180 ha in Czech Republic. The Portuguese average size (110 ha) also results from a great variance in the farms size between regions, as in the South of the country there are extensive production systems, while in the Center and North minifundium prevails. Comparing these national data with the LVID, it can be seen that: (i) the size of the plots is much smaller than in the South of Portugal, with the production of rainfed permanent pastures not being viable; (ii) the difficulties in opting for animal production in OF have the impact of not having converted pasture and forage areas, the most representative with an occupation is about $60 \%$ of the irrigated area. In line with this, a new perspective on the OF production system of the countries emerges, if this information is crossed with the percentage of farms with less than 2 ha (Greece, 50.6\%; Portugal, 46.1\%), contrasting with Spain and Italy and the Czech Republic (10.3\%). The average size of the farms in the LVID is about 0.64 ha, characteristic of a minifundium area, which is possibly a relevant aspect restricting the OF development in the LVID.

Concerning the farmers' age, the OF holders are older than non-organic farmers. The age of farms managers with and without organic area are strikingly different: farmers younger than 55 represent $61 \%$ of the organic sector, whereas they represent only $45 \%$ of the conventional sector, overall in the EU [76]. The OF farmers under 35 years old only represent $0.2 \%$ of farmers in Portugal, a lower ratio than the Spanish or the Italian ones (1.3\% and $2.1 \%$, respectively) (Table 6).

Regarding the markets, Spain and Italy have a higher annual demand of OF products (42 and 52 euros per capita), and Portugal, the lowest values of this set of countries (2 euros per capita), with a organic share of $0.2 \%$. These data highlight the relationship between the market demand and the reduced stimulus to the expansion of OF in Portugal.

The OF development in the LVID should include actions to support the farmers, like those to promote organic products such as the representation of producers in national and international exhibitions, the development of a communication plan to locate organic production or marketing units of mobile applications, and involving regional public purchases [38,39]. These strategies can help organic product marketing and their appreciation by the consumer, being the lever element for the development of this production mode. In addition, further actions to support farmers are foreseen, especially for certification, technical support and marketing, involving farmers and water user's associations, research entities and the ministry of agriculture. Lis Valley agriculture is fully dependent on the irrigation infrastructures, and aiming at its development, the National Irrigation Plan [79] foresees its modernization. To support water management and farm competitiveness through innovative practices, namely those of $\mathrm{OF}$, an operational group project is in action [80,81].

\section{Conclusions}

Organic farming can play an important role in rural development by reinforcing the penchant for sustainable agriculture and its role for ecosystem conservation. The effectiveness of OF could be particularly relevant in areas of family farming, taking advantage of the increased availability of labor and the value of short marketing circuits.

It was concluded that the farmer's land structure, low education level and high age, constrains organic farming development. Also, farmers face a number of uncertainties that explain the low adherence to this production mode, namely the certification process, the technical knowledge of new technologies, especially crop protection, and the problems of marketing and guaranteeing profitability.

It is also concluded that the role of the state is clear in prioritizing rural development policies and the promotion of $\mathrm{OF}$ through support for land restructuring, modernization of irrigation, stimulation of young farmers, conversion and implementation of innovative technologies, and the organization of farmers for better productive efficiency and market access.

Finally, the study concludes that organic farming has significant potential for stimulating rural development in the Lis Valley and that the efforts and resources of the various stakeholders need to be harmonized to deliver effective support to farmers. 
Author Contributions: F.O., F.G.d.S., H.D., and M.T. conceptualize and design the study; S.F. and R.E. performed the field observations; S.F., R.E., M.G., and J.M.G. analyzed and validated the data; S.F. wrote the paper with contributions of the other authors. All authors have read and agreed to the published version of the manuscript.

Funding: This research was conducted within project Grupo Operacional para a Gestão da Água no Vale do Lis, PDR2020-1.0.1-FEADER-030911, funded by Program PDR2020, co-funded by FEDER, Innovation Measure, Portugal.

Conflicts of Interest: The authors declare no conflict of interest.

\section{Appendix A}

Table A1. Farmers questionnaire.

\begin{tabular}{|c|c|}
\hline Question & Response Options \\
\hline \multicolumn{2}{|l|}{ Farmer age and gender } \\
\hline Farmer educational level & $\begin{array}{l}\text { Until 4th grade, } \\
5-9 \text { th grade, } \\
\text { 10-12th grade, } \\
\text { Higher education }\end{array}$ \\
\hline Relevance of agricultural activity & $\begin{array}{l}\text { Main activity and source of income, } \\
\text { Secondary activity that supports family income, } \\
\text { Without relevance }\end{array}$ \\
\hline Motivation for agriculture practice & $\begin{array}{l}\text { Family activity, } \\
\text { Continue a family business, } \\
\text { Existence of land intended to be monetize, } \\
\text { Landlord that wants to rent the parcels, } \\
\text { Family farming solidarity and commitment }\end{array}$ \\
\hline Land possession and exploitation of the parcels & $\begin{array}{l}\text { Owner and farmer, } \\
\text { Owner and not farmer, } \\
\text { Loan (free installment loan) and farmer, } \\
\text { Landlord and lessee, } \\
\text { Owner and lending }\end{array}$ \\
\hline Production destination & $\begin{array}{l}\text { Market only, } \\
\text { Partly to market, } \\
\text { Self-consumption }\end{array}$ \\
\hline Market & $\begin{array}{l}\text { Only domestic, } \\
\text { Domestic and foreign, } \\
\text { Only foreign }\end{array}$ \\
\hline Sales channels & $\begin{array}{l}\text { Final consumer, } \\
\text { Small retailers, } \\
\text { Cooperatives or wholesalers, } \\
\text { Large surfaces, } \\
\text { Other producers }\end{array}$ \\
\hline Willingness to adopt organic farming & $\begin{array}{l}\text { Affirmative, } \\
\text { Negative }\end{array}$ \\
\hline Main decision factors to adopt organic farming & $\begin{array}{l}\text { Public support, } \\
\text { Assurance of market outlets, } \\
\text { Market prices, } \\
\text { Expand cultivated area }\end{array}$ \\
\hline Additional comments & \\
\hline
\end{tabular}




\section{References}

1. Pimentel, D.; Hepperly, P.; Hanson, J.; Douds, D.; Seidel, R. Environmental, energetic, and economic comparisons of organic and conventional farming systems. BioScience 2005, 55, 573-582. [CrossRef]

2. Tal, A. Making conventional agriculture environmentally friendly: Moving beyond the glorification of organic agriculture and the demonization of conventional agriculture. Sustainability 2018, 10, 1078. [CrossRef]

3. Brzezina, N.; Biely, K.; Helfgott, A.; Kopainsky, B.; Vervoort, J.; Mathijs, E. Development of organic farming in europe at the crossroads: Looking for the way forward through system archetypes lenses. Sustainability 2017, 9, 821. [CrossRef]

4. Yadav, D.S.; Sood, P.; Thakur, S.K.; Choudhary, A.K. Assessing the training needs of agricultural extension workers about organic farming in the North-Western Himalayas. J. Org. Syst. 2013, 8, 17-27.

5. Morshedi, L.; Lashgarara, F.; Hosseini, S.J.F.; Najafabadi, M.O. The role of organic farming for improving food security from the perspective of fars farmers. Sustainability 2017, 9, 2086. [CrossRef]

6. Issa, I.; Hamm, U. Adoption of organic farming as an opportunity for syrian farmers of fresh fruit and vegetables: An application of the theory of planned behavior and structural equation modelling. Sustainability 2017, 9, 2024. [CrossRef]

7. Cristache, S.-E.; Vută, M.; Marin, E.; Cioacă, S.-I.; Vuță, M. Organic versus conventional farming-A paradigm for the sustainable development of the European countries. Sustainability 2018, 10, 4279. [CrossRef]

8. Scialabba, N.E.; Muller-Lindenlauf, M. Organic agriculture and climate change. Renew. Agric. Food Syst. 2010, 25, 158-169. [CrossRef]

9. Lynch, D.H.; MacRae, R.; Martin, R.C. The carbon and global warming potential impacts of organic farming: Does it have a significant role in an energy constrained world? Sustainability 2011, 3, 322-362. [CrossRef]

10. Diacono, M.; Persiani, A.; Testani, E.; Montemurro, F.; Ciaccia, C. Recycling agricultural wastes and by-products in organic farming: Biofertilizer production, yield performance and carbon footprint analysis. Sustainability 2019, 11, 3824. [CrossRef]

11. Arthurson, V.; Jäderlund, L. Utilization of natural farm resources for promoting high energy efficiency in low-input organic farming. Energies 2011, 4, 804-817. [CrossRef]

12. Royo-Esnal, A.; Valencia-Gredilla, F. Camelina as a rotation crop for weed control in organic farming in a semiarid Mediterranean climate. Agriculture 2018, 8, 156. [CrossRef]

13. Frabboni, L.; Tarantino, A.; Petruzzi, F.; Disciglio, G. Bio-herbicidal effects of oregano and rosemary essential oils on chamomile (Matricaria chamomilla L.) crop in organic farming system. Agronomy 2019, 9, 475. [CrossRef]

14. Neilson, B.D.; Bruening, C.A.; Stepanovic, S.; Datta, A.; Knezevic, S.; Gogos, G. Design and field testing of a combined flaming and cultivation implement for effective weed control. Appl. Eng. Agric. 2017, 33, 43-54. [CrossRef]

15. Brzozowski, L.; Mazourek, M. A sustainable agricultural future relies on the transition to organic agroecological pest management. Sustainability 2018, 10, 2023. [CrossRef]

16. European Union. Commission regulation (EC) No. 889/2008 of 5th September 2008 laying down detailed rules for the implementation of Council regulation (EC) No. 834/2007 on organic production and labelling of organic products with regard to organic production, labelling and control. Off. J. L 2008, 250, 1-84.

17. Fortune, S.; Hollies, J.; Stockdale, E.A. Effects of different potassium fertilizers suitable for use in organic farming systems on grasse/clover yields and nutrient offtakes and interactions with nitrogen supply. Soil Use Manag. 2004, 4, 403-409.

18. Pampuro, N.; Caffaro, F; Cavallo, E. Reuse of animal manure: A case study on stakeholders' perceptions about pelletized compost in northwestern Italy. Sustainability 2018, 10, 2028. [CrossRef]

19. Kolbe, H. Mineral $\mathrm{P}$ and $\mathrm{K}$ fertilization effect on crop yield response as a function of soil nutrient supply under the cultivation conditions of organic farming in Germany. J. Fur Kult. 2019, 71, 161-181.

20. Gałazka, A.; Grzeda, E.; Jończyk, K. Changes of microbial diversity in rhizosphere soils of new quality varieties of winter wheat cultivation in organic farming. Sustainability 2019, 11, 4057. [CrossRef]

21. Carr, P.M. Conservation tillage for organic farming. Agriculture 2017, 7, 19. [CrossRef]

22. Zikeli, S.; Gruber, S. Reduced tillage and no-till in organic farming systems, Germany-Status quo, potentials and challenges. Agriculture 2017, 7, 35. [CrossRef] 
23. Antichi, D.; Sbrana, M.; Martelloni, L.; Chehade, L.A.; Fontanelli, M.; Raffaelli, M.; Mazzoncini, M.; Peruzzi, A.; Frasconi, C. Agronomic performances of organic field vegetables managed with conservation agriculture techniques: A study from central Italy. Agronomy 2019, 9, 810. [CrossRef]

24. Huang, L.; Yang, J.; Cui, X.; Yang, H.; Wang, S.; Zhuan, H. Synergy and transition of recovery efficiency of nitrogen fertilizer in various rice genotypes under organic farming. Sustainability 2016, 8, 854. [CrossRef]

25. Teasdale, J.R. Contribution of cover crops to weed management in sustainable agriculture systems. J. Prod. Agric. 1996, 9, 475-479. [CrossRef]

26. Sorensen, C.; Madsen, N.; Jacobsen, B. Organic farming scenarios: Operating analysis and costs of implementing innovative technologies. Biosyst. Eng. 2005, 91, 127-137. [CrossRef]

27. Willer, H.; Lernoud, J. (Eds.) The World of Organic Agriculture. Statistics and Emerging Trends 2017; Research Institute of Organic Agriculture FiBL/Technology Innovation Platform of IFOAM—Organics International: Frick, Switzerland, 2017.

28. Sundkvist, A.; Milestad, R.; Jansson, A. On the importance of tightening feedback loops for sustainable development of food systems. Food Policy 2005, 30, 224-239. [CrossRef]

29. Morgera, E.; Caro, C.B.; Durán, G.M. Organic agriculture and the law. FAO Legis. Study 2012, 314.

30. Ingram, J. A food systems approach to researching food security and its interactions with global environmental change. Food Secur. 2011, 3, 417-431. [CrossRef]

31. Brzezina, N.; Kopainsky, B.; Mathijs, E. Can organic farming reduce vulnerabilities and enhance the resilience of the European food system? A critical assessment using system dynamics structural thinking tools. Sustainability 2016, 8, 971. [CrossRef]

32. Nemes, N. Comparative Analysis of Organic and Non-Organic Farming Systems: A Critical Assessment of Farm Profitability; FAO: Rome, Italy, 2009.

33. Testa, R.; Foderà, M.; Trapani, A.M.; Tudisca, S.; Sgroi, F. Choice between alternative investments in agriculture: The role of organic farming to avoid the abandonment of rural areas. Ecol. Eng. 2015, 83, 227-232. [CrossRef]

34. Sgroi, F.; Candela, M.; Trapani, A.M.; Forderà, M.; Squatrito, R.; Testa, R.; Tudisca, S. Economic and financial comparison between organic and conventional farming in Sicilian lemon orchards. Sustainability 2015, 7, 947-961. [CrossRef]

35. Sgroi, F.; Foderà, M.; Trapani, A.M.; Tudisca, S.; Testa, R. Cost-benefit analysis: A comparison between conventional and organic olive growing in the Mediterranean area. Ecol. Eng. 2015, 82, 542-546. [CrossRef]

36. Liontakis, A.; Tzouramani, I. Economic sustainability of organic Aloe vera farming in Greece under risk and uncertainty. Sustainability 2016, 8, 338. [CrossRef]

37. Torres, J.; Valera, D.L.; Belmonte, L.J.; Herrero-Sánchez, C. Economic and social sustainability through organic agriculture: Study of the restructuring of the citrus sector in the "Bajo Andarax" district (Spain). Sustainability 2016, 8, 918. [CrossRef]

38. Hagaton, C. National strategy for organic farming. In Proceedings of the Organic Farming: From Sustainability to Competitiveness, Samora Correia, Portugal, 19 November 2018. (In Portuguese)

39. DR. Resolution of the Council of Ministers No.110/2017, Republic Diary, 1st series—No. 144-27 July 2017. Available online: https://dre.pt/home/-/dre/107761909/details/maximized (accessed on 3 February 2020).

40. EU. Organic Farming. Available online: https://ec.europa.eu/info/food-farming-fisheries/farming/organicfarming (accessed on 26 December 2019).

41. Silva, F.G. The future of irrigation in an integrated logic of water resources management. AGROTEC 2018, 27, 46-49. (In Portuguese)

42. COBA. Environmental Impact Study of the Vale do Lis Reparcelling Project; IHERA: Lisbon, Portugal, 2001. (In Portuguese)

43. Campar, A.; Gama, A.; Cunha, L.; Jacinto, R.; Boura, I.; Medeiros, J.; Brandão, J. The Lis River Watershed-Contribution to the Study of Territory Organization and Environmental Problems; Câmara Municipal de Leiria, CCDR-Centro: Coimbra, Portugal, 1989. (In Portuguese)

44. Ferreira, S.; Oliveira, M.F.; Gonçalves, J.M.; Silva, F.G.; Teixeira, M.; Gonçalves, M.; Eugénio, R.; Damásio, H. Promover o desenvolvimento sustentável do território pela inovação agrícola. Desafios da agricultura biológica no Vale do Lis, Portugal. In Proceedings of the 10th Iberian Agroengineering Congress, Huesca, Spain, 3-6 September 2019; pp. 606-622. (In Portuguese). [CrossRef] 
45. CLIMATE-DATA.ORG. Clima Leiria. Available online: https://pt.climate-data.org/europa/portugal/leiria/ leiria-140/ (accessed on 12 December 2019).

46. INE Database. Exports of Goods by Geographic Localization (NUTS-2013), Type of Trade and Type of Goods (Combined Nomenclature—NC2); INE: Lisbon, Portugal. Available online: https://www.ine.pt/xportal/xmain? xpid=INE\&xpgid=ine_base_dados\&contexto=bd\&selTab=tab2 (accessed on 24 December 2019).

47. Pestana, M.; Gageiro, J. Análise de Dados para Ciências Sociais, 5th ed.; Edições Sílabo: Lisbon, Portugal, 2008; pp. 178-186.

48. Gujarati, D. Basic Econometrics, 3rd ed.; McGraw-Hill Book, Inc.: New York, NY, USA, 1995; pp. $372-374$.

49. Laureano, R. Teste de Hipóteses com o SPSS, 2nd ed.; Edições Sílabo: Lisbon, Portugal, 2013; pp. $126-135$.

50. INE. Farm Structure Survey. 2016. Available online: https://www.ine.pt/xportal/xmain?xpid=INE\&xpgid= ine_publicacoes\&PUBLICACOEStipo=ea\&PUBLICACOEScoleccao=107657\&selTab=tab0\&xlang=pt (accessed on 24 December 2019).

51. INE. Agricultural Census. 2009. Available online: https://www.ine.pt/xportal/xmain?xpid=INE\&xpgid=ine publicacoes\&PUBLICACOEStipo=ea\&PUBLICACOEScoleccao=107736\&PUBLICACOEStema=55505\& selTab=tab0\&xlang=pt (accessed on 24 December 2019).

52. DR. Family Farming Status. Decree Law No. 64/2018, Republic Diary, 1st Series—No. 151/2018 -7 August 2018. Available online: https://dre.pt/home/-/dre/107761909/details/maximized (accessed on 3 February 2020).

53. EU. Family Farming. Available online: https://ec.europa.eu/agriculture/family-farming_en (accessed on 24 December 2019).

54. EU. Agriculture and rural development. In Proceedings of the Family Farming: A Dialogue Towards More Sustainable and Resilient Farming in Europe and the World, Brussels, Belgium, 29 November 2013.

55. DR. Decree Law No. 37/2013, Republic Diary, 1st Series, No. 51, 13 March 2013. Available online: https://dre.pt/home/-/dre/107761909/details/maximized (accessed on 3 February 2020).

56. Murray, L.; McGrath, M. Sustainable Farmland Investment Strategies: An Introduction to Current; Yale School of Management \& Yale School of Forestry and Environmental Studies: New Haven, CT, USA, 2016.

57. Ruhf, K.; Wagner, B. Farmland Investors: An Exploration for New England and Beyond; Land Access Project: Keen, NH, USA, 2013.

58. Carolan, M.S.; Mayerfeld, D.; Bel, M.M.; Exner, R. Rented land: Barriers to sustainable agriculture. J. Soil Water Conserv. 2004, 59, 70A-75A.

59. Ciaian, P.; Kancs, D.A.; Swinnen, J.; Van Herck, C.; Vranken, L. Rental Market Regulations for Agricultural Land in EU Member States and Candidate Countries; Factor Market Working Papers; CEPS: Brussels, Belgium, 2012; pp. 1-24.

60. Marín, L.; Nicolás, C.; Rubio, A. How gender, age and education influence the entrepreneur's social orientation: The moderating effect of economic development. Sustainability 2019, 11, 4514. [CrossRef]

61. EIP-AGRI Home Page. Available online: https:/ec.europa.eu/eip/agriculture/en (accessed on 5 December 2019).

62. Oliveira, M.F.; Carvalho, L. New farmers in Portuguese agriculture: The role of younger farmers. In Proceedings of the 7th International Conference on Localized Agri-Food Systems "Changes for the New Rurality in a Changing World", Stockholm, Sweden, 8-10 May 2016; pp. 57-58.

63. Verhoog, H.; Matze, M.; van Bueren, E.L.; Baars, T. The role of the concept of the natural (naturalness) in organic farming. J. Agric. Environ. Ethics 2003, 16, 29-49. [CrossRef]

64. Nandwani, D.; Nwosisi, S. Global trends in organic agriculture. In Organic Farming for Sustainable Agriculture; Springer: Cham, Switzerland, 2016; pp. 1-36.

65. McGee, J.A.; Alvarez, C. Sustaining without changing: The metabolic rift of certified organic farming. Sustainability 2016, 8, 115. [CrossRef]

66. Siepmann, L.; Nicholas, K.A. German winegrowers' motives and barriers to convert to organic farming. Sustainability 2018, 10, 4215. [CrossRef]

67. Damayanti, M.; Nugroho, P.; Tyas, W.P. Norms in community-based organic farming. Agriculture 2018, 8, 185. [CrossRef]

68. Altieri, M.A. Agroecology, small farms, and food sovereignty. Mon. Rev. 2009, 3, 61. [CrossRef]

69. Jouzi, Z.; Azadi, H.; Taheri, F.; Zarafshani, K.; Gebrehiwot, K.; Van Passel, S.; Lebailly, P. Organic farming and small-scale farmers: Main opportunities and challenges. Ecol. Econ. 2017, 132, 144-154. [CrossRef] 
70. DGAV Home Page. Available online: www.dgv.min-agricultura.pt/portal/page/portal/DGV (accessed on 12 December 2019).

71. Mastronardi, L.; Marino, D.; Cavallo, A.; Giannelli, A. Exploring the role of farmers in short food supply chains: The case of Italy. Int. Food Agribus. Manag. Rev. 2015, 18, 109-130.

72. Kneafsey, M.; Venn, L.; Schmutz, U.; Balázs, B.; Trenchard, L.; Eyden-Wood, P.; Bos, E.; Sutton, G.; Blackett, M. Short Food Supply Chains and Local Food Systems in the EU. A State of Play of Their Socio-Economic Characteristics; Technical Report No. 25911; Santini, F., Gomez y Paloma, S., Eds.; Publications Office of the European Union: Luxembourg, 2013.

73. EPRSLibrary. Local Agriculture and Short Food Supply Chains. European Parliamentary Research Service Blog. 14 October 2013. Available online: https://epthinktank.eu/2013/10/14/local-agriculture-and-short-foodsupply-chains/ (accessed on 12 May 2019).

74. Gonçalves, J.M. Recovery of traditional irrigation systems to develop rural tourism. emRede Revista da Rede Rural Nacional 2019, 9, 28-29. (In Portuguese)

75. IFOAM. Greece. Available online: https://www.ifoam-eu.org/en/greece (accessed on 1 February 2020).

76. Rossi, R. Facts and Figures on Organic Agriculture in the European Union; DG Agriculture and Rural Development, Unit Economic Analysis of EU Agriculture: Brussels, Belgium, 2013.

77. EUROSTAT. Agriculture Database. Available online: https://ec.europa.eu/eurostat/web/agriculture/data/ database (accessed on 1 February 2020).

78. Charlier, H. Structure of agriculture holdings in the EU by age of holder. Stat. Focus 2003, 2, 4.

79. Ministry of Agriculture, Forestry and Rural Development of the Republic of Portugal. Portuguese Irrigation Plan 2018. Available online: https://www.dgadr.gov.pt/11-regadio-e-aproveitamentos-hidroagricolas/716programa-nacional-de-regadios (accessed on 12 December 2019).

80. Gonçalves, J.M.; Nunes, M.; Eugénio, R.; Ferreira, S.; Amador, P.; Filipe, O.; Duarte, I.M.; Teixeira, M.; Marques, H.; Oliveira, F.; et al. Estudo de caso de monitorização da água no aproveitamento hidroagrícola do Vale do Lis, Portugal. In Proceedings of the 10th Iberian Agroengineering Congress, Huesca, Spain, 3-6 September 2019. (In Portuguese)

81. Oliveira, M.F.; Silva, F.G.; Ferreira, S.; Teixeira, M.; Damásio, H.; Ferreira, A.D.; Gonçalves, J.M. Innovations in sustainable agriculture: Case study of Lis Valley irrigation district, Portugal. Sustainability 2019, 11, 331. [CrossRef]

(C) 2020 by the authors. Licensee MDPI, Basel, Switzerland. This article is an open access article distributed under the terms and conditions of the Creative Commons Attribution (CC BY) license (http://creativecommons.org/licenses/by/4.0/). 